\title{
The pure anti-androgen bicalutamide inhibits cyclin A expression both in androgen-dependent and -independent cell lines
}

\author{
HIROSHI KATAYAMA ${ }^{1,2,3}$, TERUKO MURASHIMA ${ }^{1,2}$, YOSHIKO SAEKI ${ }^{2}$ and YASUKO NISHIZAWA Y,2 $^{1,2}$ \\ ${ }^{1}$ Laboratory of Clinical and Experimental Pathophysiology, Graduate School of Pharmaceutical Sciences, \\ Osaka University, 1-6 Yamadaoka, Suita, Osaka 565-0871; ${ }^{2}$ Department of Pathology, Research Institute, \\ Osaka Medical Center for Cancer and Cardiovascular Diseases, 1-3-3 Nakamichi, Higashinari, Osaka 537-8511; \\ ${ }^{3}$ Preclinical Sciences Department, Regulatory Division, Research and Development, AstraZeneca K.K., \\ Umeda Sky Building Tower East, 1-1-88 Ohyodo-naka, Kita-ku, Osaka 531-0076, Japan
}

Received October 15, 2009; Accepted November 23, 2009

DOI: 10.3892/ijo_00000529

\begin{abstract}
We investigated the effects of testosterone and the pure anti-androgen, bicalutamide, on DNA synthesis and cell cycle in androgen-sensitive or -insensitive human and mouse cell lines by ${ }^{3} \mathrm{H}$-thymidine incorporation, flow cytometry, RT-PCR and Western blotting. In androgen-dependent mouse SC-3 cells, testosterone induced DNA synthesis, shift of cell cycle distribution from $\mathrm{G} 0 / \mathrm{G} 1$ to $\mathrm{S} / \mathrm{G} 2 / \mathrm{M}$ and expression of cyclin A. The induction was preceded by that of fibroblast growth factor 8 (FGF-8), and completely blocked by monoclonal antibody to FGF-8. Dihydrotestosterone (DHT) induced cyclin A expression in androgen-sensitive human prostate cancer cells, but not in androgen-independent cell lines. Bicalutamide almost completely inhibited these androgen-dependent effects both in LNCaP and SC-3 cells, but had no or limited effect on androgen-independent or FGF-8-induced DNA synthesis, and FGF-8 induced cyclin A expression. Interestingly, bicalutamide inhibited both DNA synthesis and the cyclin A expression in androgenindependent human cell lines in serum-free condition. A MEK1/2 inhibitor U0126 blocked both androgen- and rFGF-8-induced DNA synthesis. Overall, bicalutamide inhibits the cyclin A expression possibly by inhibiting FGF-8 mRNA expression and FGF-8 protein secretion but not by inhibiting FGF receptor (FGFR) signalling in androgendependent cell lines, and by other mechanisms in androgenindependent cell lines. The results suggest that combination with compounds such as FGFR signalling inhibitors may provide additional benefits to anti-androgens. It is also suggested that cyclin A could be a sensitive marker for
\end{abstract}

Correspondence to: Yasuko Nishizawa, Department of Pathology, Research Institute, Osaka Medical Center for Cancer and Cardiovascular Diseases, 1-3-3 Nakamichi, Higashinari, Osaka 537-8511, Japan

E-mail: nisizawa-ya@mc.pref.osaka.jp

Key words: androgen, cyclin A, bicalutamide, FGF-8 androgen-induced cancer growth and for the growth inhibitory effects of anti-androgen.

\section{Introduction}

Steroid hormones, such as androgens or estrogens, induce proliferation of various tumor cells. Typical examples are breast, endometrial and prostate cancer. It has been suggested that steroid hormone-dependent cell growth is mediated by growth factors, such as fibroblast growth factor (FGF), epidermal growth factor (EGF) and interleukin-6 (IL-6), induced by steroid hormone-steroid hormone receptor complexes. For example, the crosstalk between androgen receptor (AR) and EGF receptor (EGFR)/human epidermal growth factor receptor type 2 (HER2) signalling pathways has been disrupted with a combination of bicalutamide (casodex), a pure anti-androgen, and an EGFR tyrosine kinase inhibitor gefitinib (1). In addition, ligand-independent transactivation of AR by growth factors has been welldocumented and could be one of the mechanisms of androgendependent and androgen-resistant cell proliferation (2).

Although there are some reports on molecular mechanism of androgen-regulated tumor cell growth $(2,3)$, it has not been fully investigated. Aberrations in cell cycle progression are thought to be one of the most common features of human malignancies. Cell cycle progression is regulated by cyclindependent kinases (CDKs), and their activities are regulated by cyclins and CDK inhibitors (CKIs). It has also been reported that androgen regulates the expression of key cell cycle regulators (4). To investigate the androgen-dependent cell growth including the relationship between androgen and the expression of key cell cycle regulators, we used several androgen-sensitive and -insensitive cell lines; androgen-sensitive human prostate cancer cell line LNCaP (AR-positive), mouse androgen-dependent cell line SC-3 (AR-positive), and androgen-insensitive human prostate cancer cell lines DU145 and PC-3 (AR-negative).

LNCaP has been widely used as a standard cell line to investigate androgen-dependent cell growth. DU145 and PC-3 are well-known as androgen-insensitive cell lines and also used as control cell lines for the investigation of the 
androgen-dependent cell growth. Although there is no doubt that $\mathrm{LNCaP}$ is androgen-sensitive, it is not completely androgen-dependent (5). If the androgen-dependent effects are investigated in $\mathrm{LNCaP}$ cells, this should be taken into account, and additional investigation may be required to claim that the effect is androgen-specific, e.g. by using other androgen-sensitive cell lines, or by testing in serum-free condition.

The androgen-dependent mouse mammary carcinoma, Shionogi carcinoma 115 (SC115), was established by Minesita and Yamaguchi (6). SC-3 is a highly androgen-dependent cell line isolated from SC115 (7), and it has been shown that androgen-dependent growth of SC-3 cells is mediated in an autocrine manner by an androgen-induced growth factor (AIGF), FGF-8 (8). In SC-3 cells, androgen induces FGF-8 mRNA expression. There is clinical evidence suggesting that FGF-8 has an important role in hormone-responsive cancers, such as prostate cancer (9) or breast cancer (10). Therefore, SC-3 cells could provide a clue to elucidate the mechanism of tumor cell growth induced by steroid hormone activity. In addition, it is suitable to investigate the androgen-specific effects with SC-3 cells together with LNCaP cells because of its highly androgen-dependent nature.

Here we report the effects of androgen on the expression of cell cycle regulators and the inhibition of these effects by bicalutamide both in the androgen-dependent and -independent cell lines in serum-free condition.

\section{Materials and methods}

Materials. Human prostate cancer cell lines were obtained from Dainippon Pharmaceuticals (for LNCaP.FGC and PC-3, Osaka, Japan) and American Type Culture Collection (for DU145, Manassas, USA). The non-steroidal pure antiandrogen bicalutamide (casodex) was from AstraZeneca Pharmaceuticals (Macclesfield, UK). Anti-cyclin A monoclonal antibody (C-4710), CelLytic-M mammalian cell lysis/ extraction reagent, bovine serum albumin (BSA, fatty acid free), mitogen-activated protein kinase-extracellular signal-regulated kinase kinase (MEK) 1/2 inhibitor U0126, RPMI-1640, trypsin and activated charcoal were obtained from Sigma Chemical Co. (St. Louis, MO, USA). Recombinant FGF-8b (rFGF-8) and anti-FGF-8b monocloncal antibody were from R\&D Systems (Minneapolis, MN, USA). Anti-GAPDH monoclonal antibody was from Novus Biologicals (Littleton, CO, USA). Envision ${ }^{+}$was from Dako Japan (Tokyo, Japan). Dextran T-70 was from Pharmacia Fine Chemicals (Uppsala, Sweden). Eagle's minimum essential medium (MEM) and Ham's F-12 were from Nissui Pharmaceutical Co., Ltd. (Tokyo, Japan). Fetal bovine serum (FBS) was from JRH Biosciences. TRIzol reagent was from Gibco BRL (Grand Island, NY, USA). Agarose SFR gel was from Amresco (Solon, OH, USA). BioRad Protein Assay kit was from BioRad (Hercules, CA, USA). NuPAGE Pre-Cast gel system was from Invitrogen (Carlsbad, CA, USA). [methyl- ${ }^{3} \mathrm{H}$ ] thymidine, Ready-To-Go beads, PCR primers, polyvinylidene difluoride (PVDF) membrane (Hybond-P) and ECL Western blotting system were purchased from Amersham Pharmacia Biotech (Little Chalfont, UK).
Cell culture. SC-3 cells, established from an androgendependent mouse mammary tumor SC115, were maintained in MEM containing 2\% dextran-coated charcoal-treated fetal bovine serum (DCC-FBS) and $10 \mathrm{nM}$ testosterone at $37^{\circ} \mathrm{C}$, and human prostate cancer cell lines were maintained in the RPMI-1640 (LNCaP and DU145) or Ham's F-12 (PC-3) medium supplemented with $10 \% \mathrm{FBS}$ at $37^{\circ} \mathrm{C}$.

Cell growth experiments. For experiments, firstly maintenance medium was changed to testosterone (T) or dihydrotestosterone (DHT)-free MEM (SC-3), RPMI-1640 (LNCaP and DU145) or Ham's F-12 (PC-3) containing 2\% DCC-FBS. Cells were seeded into 96 -well plates $\left(0.3-3 \times 10^{4}\right.$ cells/well, for DNA synthesis experiment), $60-\mathrm{mm}$ dishes $\left(5 \times 10^{5}\right.$ cells/ dish) or $100-\mathrm{mm}$ dishes $\left(2 \times 10^{6}\right.$ cells/dish, for RNA or cell lysate preparation). The following day (day 0), the medium was replaced with the growth medium, HMB0.1 medium [HAM F-12-MEM (1:1, v/v) containing 0.1\% BSA (essential fatty acid-free)] with or without T or DHT (0.1-1000 nM), rFGF-8 (3-100 ng/ml) and various concentrations of inhibitors (bicalutamide and U0126). Androgens and inhibitors were dissolved in ethanol (androgens and bicalutamide) or DMSO (U0126). Final concentration of vehicle was up to $0.4 \%$ in total. We confirmed that the vehicles did not affect DNA synthesis of the cell lines tested.

For DNA synthesis experiment in all cell lines, after 3-day culture with the growth medium as described above, cells were pulsed with ${ }^{3} \mathrm{H}$-thymidine $(0.33 \mu \mathrm{Ci} /$ well $)$ for $2 \mathrm{~h}(5 \mathrm{~h}$ for $\mathrm{LNCaP}$ cells) at $37^{\circ} \mathrm{C}$ and the radioactivity incorporated into the cells were measured. For RNA or cell lysate preparation, cells were harvested on days 1-3 except for time course experiments.

For time course experiments, SC-3 cells were seeded into $100-\mathrm{mm}$ dishes $\left(2 \times 10^{6}\right.$ cells/dish $)$ containing T-free MEM with $2 \%$ DCC-FBS. The following day $(-48 \mathrm{~h})$, the medium was replaced with HMB0.1 medium without T. After 2 days of testosterone deprivation (time 0 ), medium was changed again to HMB0.1 medium with or without $\mathrm{T}(1 \mathrm{nM})$ and bicalutamide $(1 \mu \mathrm{M})$. Cells were harvested at indicated hours of incubation.

Flow cytometry analysis. Exponentially growing SC-3 cells were cultured with or without $\mathrm{T}$ and bicalutamide as described above. For cell cycle distribution analysis, cells were fixed for $>4 \mathrm{~h}$ at $4^{\circ} \mathrm{C}$ with $70 \%$ ethanol and incubated with RNase A (final $100 \mu \mathrm{g} / \mathrm{ml}$ ) for $30 \mathrm{~min}$ at $37^{\circ} \mathrm{C}$ and the DNA intercalating dye, propidium iodide (final $50 \mu \mathrm{g} / \mathrm{ml}$ ) for $30 \mathrm{~min}$ at room temperature. Flow cytometry analysis was performed using FACSCalibur (Becton-Dickinson Japan, Tokyo) comparing vehicle control, $\mathrm{T}$-treated and $\mathrm{T}$ and bicalutamidetreated cells.

RNA isolation. After aspiration of the medium, cells were harvested with a cell scraper into TRIzol reagent and stored at $-80^{\circ} \mathrm{C}$ until use. RNA isolation was done according to the manufacturer's instruction.

Cell lysate preparation. Cells were washed once with phosphate-buffered saline (PBS) and incubate the cells with CelLytic-M reagent $(1 \mathrm{ml} / \mathrm{dish})$ at $4^{\circ} \mathrm{C}$ for $15 \mathrm{~min}$. Then cells 
Table I. RT-PCR conditions.

\begin{tabular}{|c|c|c|c|c|c|c|}
\hline \multirow[b]{2}{*}{ Molecules } & \multirow[b]{2}{*}{ Primer sequences } & \multicolumn{3}{|c|}{ PCR condition } & \multirow[b]{2}{*}{$\begin{array}{l}\text { No. of } \\
\text { cycles }\end{array}$} & \multirow[b]{2}{*}{$\begin{array}{l}\text { Length } \\
\text { of PCR } \\
\text { product } \\
\text { (bp) }\end{array}$} \\
\hline & & Denaturation & Annealing & Extension & & \\
\hline Mouse cyclin A & $\begin{array}{l}\text { (F) 5'-CACTCACACACTTAGTGTCTCTGGTGGG-3' } \\
\text { (R) 5'-GCCGCGATGCCGGGCACCTCGAGGCATTCG-3' }\end{array}$ & $95^{\circ} \mathrm{C}, 30 \mathrm{sec}$ & $56^{\circ} \mathrm{C}, 1 \mathrm{~min}$ & $72^{\circ} \mathrm{C}, 2 \mathrm{~min}$ & 30 & 1277 \\
\hline Human cyclin A & $\begin{array}{l}\text { (F) 5'-GTCTTCCATGTCAGTGCTGA-3' } \\
\text { (R) 5'-CAACTTTGCAGTTTGCAGGC-3' }\end{array}$ & $94^{\circ} \mathrm{C}, 1 \mathrm{~min}$ & $55^{\circ} \mathrm{C}, 1 \mathrm{~min}$ & $72^{\circ} \mathrm{C}, 2 \mathrm{~min}$ & 25 & 260 \\
\hline Mouse cyclin D1 & $\begin{array}{l}\text { (F) 5'-CGCCTTCCGTTTCTTACTTCA-3' } \\
\text { (R) 5'-AACTTCTCGGCAGTCAGGGGA-3' }\end{array}$ & $94^{\circ} \mathrm{C}, 1 \mathrm{~min}$ & $60^{\circ} \mathrm{C}, 1 \mathrm{~min}$ & $72^{\circ} \mathrm{C}, 2 \mathrm{~min}$ & 30 & 250 \\
\hline Mouse cyclin E & $\begin{array}{l}\text { (F) 5'-CTGGCTGAATGTTTATGTCC-3' } \\
\text { (R) 5'-TCTTTGCTTGGGCTTTGTCC-3' }\end{array}$ & $94^{\circ} \mathrm{C}, 45 \mathrm{sec}$ & $58^{\circ} \mathrm{C}, 45 \mathrm{sec}$ & $72^{\circ} \mathrm{C}, 1.5 \mathrm{~min}$ & 30 & 386 \\
\hline Mouse $\mathrm{p} 21^{\text {Waf } 1 / \mathrm{Cip} 1}$ & $\begin{array}{l}\text { (F) 5'-AGCCTGAAGACTGTGATGGG-3' } \\
\text { (R) 5'-AAAGTTCCACCGTTCTCGG-3' }\end{array}$ & $94^{\circ} \mathrm{C}, 45 \mathrm{sec}$ & $62^{\circ} \mathrm{C}, 45 \mathrm{sec}$ & $72^{\circ} \mathrm{C}, 1 \mathrm{~min}$ & 27 & 228 \\
\hline Mouse p $27^{\mathrm{Kip} 1}$ & $\begin{array}{l}\text { (F) 5'-CCCGCCCGAGGAGGAAGATGTCAAAC-3' } \\
\text { (R) 5'-CCCTTTTGTTTTGCGAAGAAGAATCT-3' }\end{array}$ & $94^{\circ} \mathrm{C}, 1 \mathrm{~min}$ & $59^{\circ} \mathrm{C}, 1 \mathrm{~min}$ & $72^{\circ} \mathrm{C}, 1 \mathrm{~min}$ & 30 & 516 \\
\hline FGF-8 & $\begin{array}{l}\text { (F) 5'-TTTACACAGCATGTGAGGGAG-3' } \\
\text { (R) 5'-GTAGTTGAGGAACTCGAAGCG-3' }\end{array}$ & $95^{\circ} \mathrm{C}, 1 \mathrm{~min}$ & $55^{\circ} \mathrm{C}, 1 \mathrm{~min}$ & $72^{\circ} \mathrm{C}, 1 \mathrm{~min}$ & 30 & 494 \\
\hline $\mathrm{AR}$ & $\begin{array}{l}\text { (F) 5'-TCTCAAGAGTTTGGATGGCTCC-3' } \\
\text { (R) 5' -TCACTGGGTGTGGAAATAGATG-3' }\end{array}$ & $94^{\circ} \mathrm{C}, 45 \mathrm{sec}$ & $58^{\circ} \mathrm{C}, 45 \mathrm{sec}$ & $72^{\circ} \mathrm{C}, 1 \mathrm{~min}$ & 20 & 390 \\
\hline Mouse GAPDH & $\begin{array}{l}\text { (F) 5'-ATCTTCCAGGAGCGAGACCCC-3' } \\
\text { (R) 5'-TCCACAATGCCAAAGTTGTCATGG-3' }\end{array}$ & $94^{\circ} \mathrm{C}, 45 \mathrm{sec}$ & $55^{\circ} \mathrm{C}, 45 \mathrm{sec}$ & $72^{\circ} \mathrm{C}, 1 \mathrm{~min}$ & 25 & 289 \\
\hline Human GAPDH & $\begin{array}{l}\text { (F) 5'-CCACCCATGGCAAATTCCATGGCA-3' } \\
\text { (R) 5'-TCTAGACGGCAGGTCAGGTCCACC-3' }\end{array}$ & $94^{\circ} \mathrm{C}, 1 \mathrm{~min}$ & $55^{\circ} \mathrm{C}, 1 \mathrm{~min}$ & $72^{\circ} \mathrm{C}, 1 \mathrm{~min}$ & 32 & 598 \\
\hline
\end{tabular}

were removed from plates by cell scraper. The lysed cells were centrifuged for $15 \mathrm{~min}$ at $12,000 \mathrm{x} \mathrm{g}$ and the supernatant was used for Western blot analysis. Protein concentration was determined using BioRad Protein Assay kit.

$R T$-PCR. RT-PCR (semi-quantitative) was performed using Ready-To-Go beads. First strand cDNA was synthesized at $42^{\circ} \mathrm{C}$ for 30 min using $1 \mu \mathrm{g}$ of total RNA and $\mathrm{pd}(\mathrm{T})_{12-18}$ primer (except for FGF-8 and mouse glyceraldehyde-3phosphate dehydrogenase, mGAPDH, using specific primers). PCR reaction was performed using sequence specific primers. Sequences of each set of primers and detailed PCR conditions are described in Table I (11-19). Final extension was at $72^{\circ} \mathrm{C}$ for $10 \mathrm{~min}$. PCR products were confirmed in $2 \%$ agarose SFR gel with ethidium bromide except $1 \%$ for mouse cyclin A. A house-keeping gene GAPDH was used to normalize the target gene expression.

Western blot analysis. Cell lysates were fractionated by electrophoresis with NuPAGE 4-12\% Bis-Tris gel, and electrotransfered to PVDF membrane (Hybond-P). Human and mouse cyclin A and FGF-8 protein levels were determined with primary antibodies, Envision ${ }^{+}$as a secondary antibody and ECL system. GAPDH was used as a loading control.
Data analysis. Results of the effects on androgen-induced DNA synthesis were expressed as the mean \pm standard errors of mean (SEM) of four replicates per group. Values of $50 \%$ inhibitory concentration $\left(\mathrm{IC}_{50}\right)$ were calculated using JMP version 6 (SAS Institute Japan, Tokyo). Cell cycle distribution analysis was done with ModFit LT version 3.0.

\section{Results}

Growth stimulatory effects of androgen in SC-3 and human prostate cancer cells. The effects of the androgen-induced cell growth were examined as DNA synthesis measured by ${ }^{3} \mathrm{H}$-thymidine incorporation in $\mathrm{SC}-3$ and human prostate cancer cell lines.

As shown in Fig. 1A, testosterone stimulated the uptake of ${ }^{3} \mathrm{H}$-thymidine in a concentration-dependent manner in SC-3 cells, as reported previously (5). A non-steroidal pure antiandrogen, bicalutamide caused right hand shift of the growth stimulatory curve of the testosterone in SC-3 cells, suggesting its competitive inhibition on testosterone-induced DNA synthesis.

Likewise, DHT stimulated the DNA synthesis in human prostate cancer LNCaP cells dose-dependently, but not in androgen-independent human prostate cancer DU145 and PC-3 cells, as expected (Fig. 1B). However, the growth of 
(A)

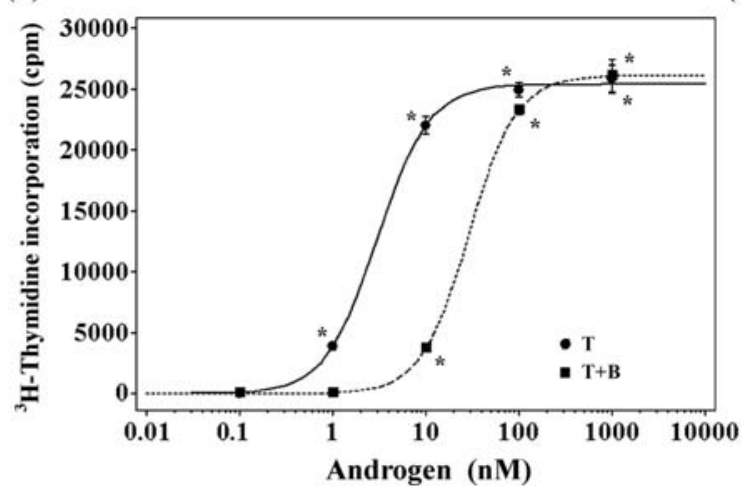

(B)

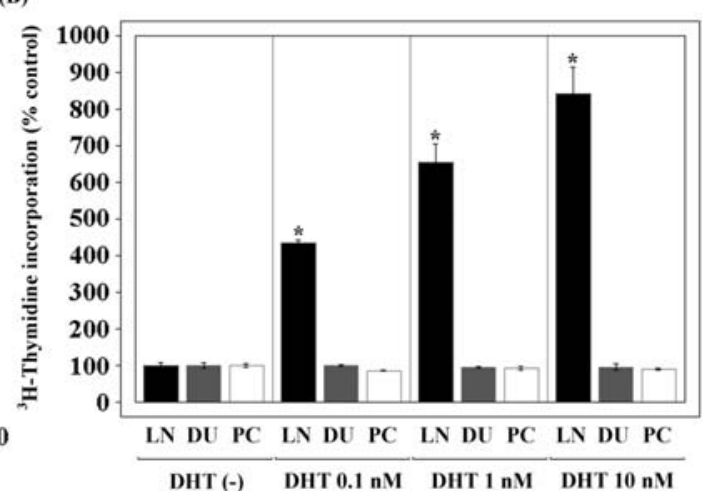

Figure 1. Growth stimulatory effect of androgen in SC-3 and human prostate cancer cells ( $n=4$, mean \pm SEM). (A) SC-3 cells were seeded into a 96 -well plate $\left(8 \times 10^{3}\right.$ cells/well) and medium was changed to HMB0.1 with testosterone alone (0.1-1000 nM), or in combination with bicalutamide $(1 \mu \mathrm{M})$ the following day (day 0). Cells were pulsed with ${ }^{3} \mathrm{H}$-thymidine on day 3 for $2 \mathrm{~h}$ at $37^{\circ} \mathrm{C}$ and the radioactivity incorporated into the cells was measured. (B) Human prostate cancer cells were seeded into a 96 -well plate $\left(0.3-3 \times 10^{4}\right.$ cells/well) and medium was changed to HMB0.1 with dihydrotestosterone (0.1-10 nM) the following day (day 0). Cells were pulsed with ${ }^{3} \mathrm{H}$-thymidine on day 3 for $2 \mathrm{~h}\left(5 \mathrm{~h}\right.$ for $\mathrm{LNCaP}$ cells) at $37^{\circ} \mathrm{C}$ and the radioactivity incorporated into the cells was measured. T, testosterone; DHT, dihydrotestosterone; BIC, bicalutamide; LN, LNCaP; DU, DU145; PC, PC-3.

LNCaP cells were not fully androgen-dependent both in serum-supplemented and serum-free conditions based on the fact that ${ }^{3} \mathrm{H}$-thymidine incorporation without DHT were $\sim 10-15 \%$ of those at physiological concentrations of DHT, i.e. 1 and $10 \mathrm{nM}$.

Growth inhibitory effects of bicalutamide in SC-3 and human prostate cancer cells. Growth inhibitory effects of bicalutamide on the androgen-induced and androgen-independent cell growth were examined as DNA synthesis measured by ${ }^{3} \mathrm{H}$-thymidine incorporation.

Bicalutamide inhibited androgen-induced DNA synthesis in a concentration-dependent manner in SC-3 cells (Fig. 2A). $\mathrm{IC}_{50}$ values of bicalutamide on the DNA synthesis induced by testosterone $1 \mathrm{nM}$, DHT 1 or $10 \mathrm{nM}$ were 82.2 (69.1-96.1) nM, $5.06(3.62-7.43)$ and $20.9(18.8-23.3) \mu \mathrm{M}(95 \%$ confidence limits), respectively. No growth stimulatory effect was observed with bicalutamide alone up to $30 \mu \mathrm{M}$ (data not shown). The concentration ratio between testosterone or DHT and bicalutamide required for full inhibition was needed to be 1:1,000 (Fig. 2A) and 1:10,000-30,000 (Fig. 2A), respectively. The results were consistent with those reported by Darbre et al with S115 cells (20).

Bicalutamide also showed dose-dependent inhibition on the DHT-induced growth of LNCaP cells, but the effects were limited to androgen-dependent component, i.e., no effect on the growth without DHT up to $30 \mu \mathrm{M}$ (Fig. 2B). $\mathrm{IC}_{50}$ values of bicalutamide at DHT 1 and $10 \mathrm{nM}$ were 124 (47-302) and 660 (352-1,197) nM, respectively. Interestingly, bicalutamide inhibited the DNA synthesis in androgenindependent prostate cancer cells, PC-3 and DU145 at $30 \mu \mathrm{M}$ (Fig. 2C and D) in androgen-independent manner.

In the time course experiments using SC-3 cells, statistically significant effects were observed on day 2 and afterwards (data not shown). It is anticipated that the early changes in cell cycle distribution and mRNA expression of cell cycle regulator genes would be observed within three days of culture.

For further investigation, testosterone and dihydrotestosterone were selected for SC-3 and LNCaP cells to investigate androgen-dependent effects, respectively, based on the findings above and the fact that these androgens have been widely used for investigations in each cell line; testosterone (1 nM) was selected for SC-3 cells to investigate very early, sensitive events induced by testosterone, whereas physiological concentration of dihydrotestosterone $(10 \mathrm{nM})$ was selected for human prostate cancer cells to investigate the clinical relevancy of the effects.

Effect of testosterone and bicalutamide on cell cycle distribution. The effects on testosterone-induced changes in cell cycle distribution in SC-3 cells was analysed using flow cytometry. Results are shown in Fig. 3A. Testosterone $(1 \mathrm{nM})$ induced shift of cell cycle distribution from G0/G1 to S/G2/M. This shift of the cell cycle distribution was almost completely blocked by bicalutamide at $1 \mu \mathrm{M}$, whereas bicalutamide itself did not induce a change in cell cycle distribution.

Androgen-induced changes in cell cycle regulator $m R N A$ levels and the inhibitory effects of bicalutamide. The effects on androgen-induced changes in cell cycle regulator mRNA levels were examined by RT-PCR. The effects of bicalutamide on these changes were also examined.

A typical example of the results is shown in Fig. 3B for $\mathrm{SC}-3$ cells. As previously reported (8), FGF-8 (AIGF) mRNA was upregulated by testosterone in SC-3 cells. In the cell cycle regulators examined, mRNA levels of cyclin A were markedly upregulated by testosterone. The effect was almost completely inhibited by bicalutamide. Although there were tendencies of increase in transcription of cyclin $\mathrm{D}_{1}$ and $\mathrm{E}$ by testosterone, no clear change was observed in the cell cycle regulators examined other than cyclin A. There was no consistent change in $\mathrm{p} 16^{\mathrm{INK} 4 \mathrm{a}}$ expression (data not shown). Bicalutamide, at $1 \mu \mathrm{M}$, almost completely inhibited testosterone-induced upregulation of FGF-8 and cyclin A mRNA.

As the androgen-induced effects on mRNA expression of cell cycle regulators were limited to that of cyclin A, and the effects were possibly related to FGF-8, the effects were also investigated in human prostate cancer cell lines. As shown in Fig. 3C, $10 \mathrm{nM}$ of DHT induced the mRNA expression of 
(A) SC-3

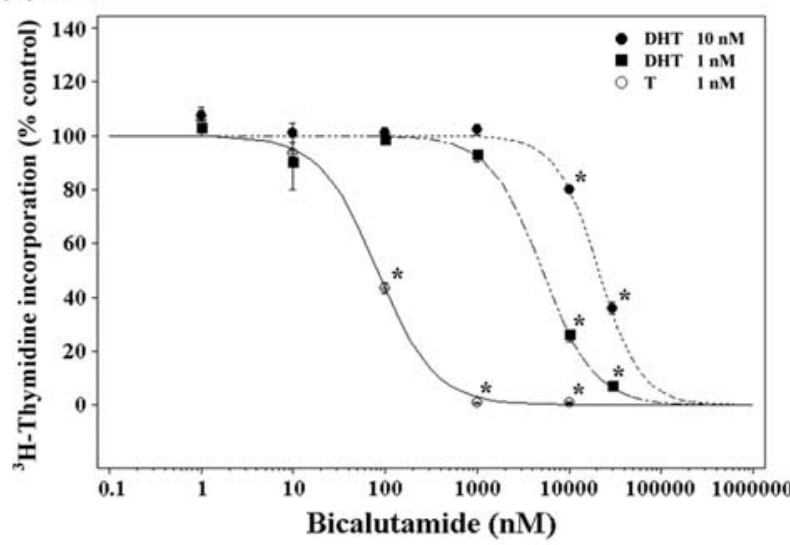

(C) DU 145

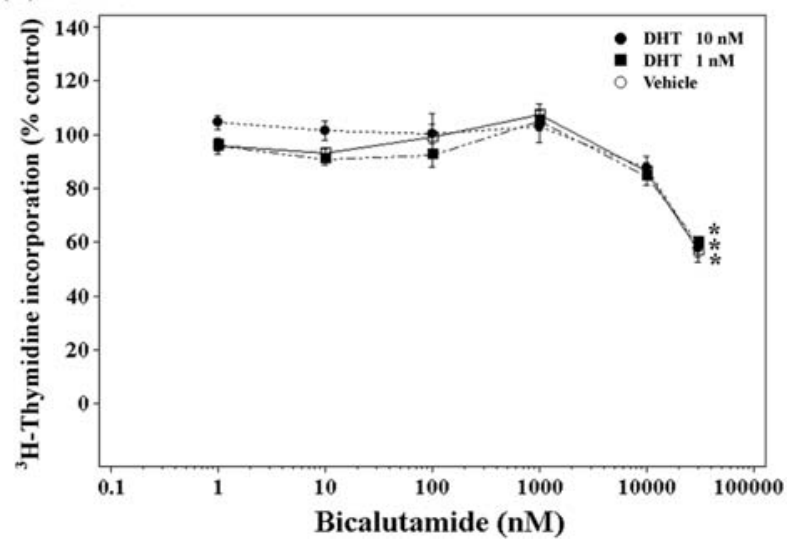

(B) LNCaP

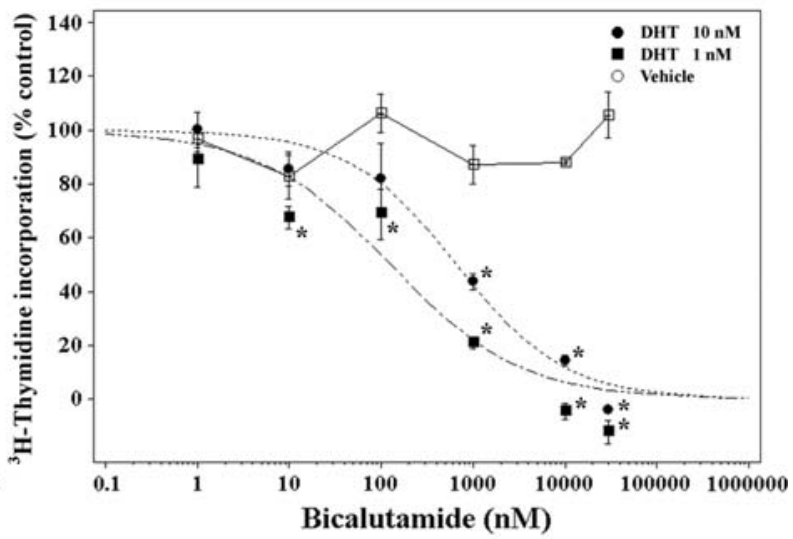

(D) PC-3

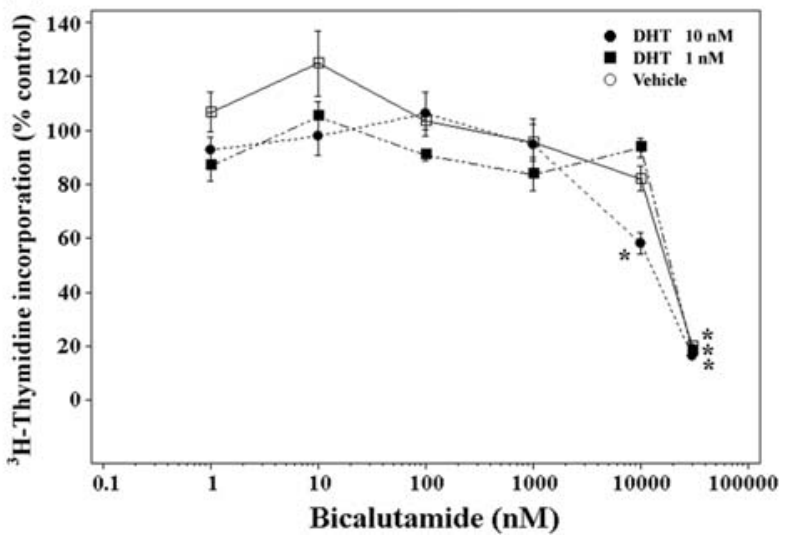

Figure 2. Concentration-dependent growth inhibitory effects of bicalutamide on androgen induced growth ( $\mathrm{n}=4$, mean \pm SEM). (A) SC-3 cells were seeded into a 96-well plate and pulsed with ${ }^{3} \mathrm{H}$-thymidine as described in Fig. 1, except for medium (HMB0.1) with testosterone (1 nM) or dihydrotestosterone (1 or $10 \mathrm{nM})$ and various concentrations of bicalutamide (1 nM-30 $\mu \mathrm{M})$. (B)-(D) Human prostate cancer cells were seeded into a 96-well plate and pulsed with ${ }^{3} \mathrm{H}$-thymidine as described in Fig. 1, except for medium (HMB0.1) with DHT (0, 1 or $\left.10 \mathrm{nM}\right)$ and various concentrations of bicalutamide (1 nM-30 $\left.\mu \mathrm{M}\right)$. " $\mathrm{p}<0.05$ (comparison with vehicle control, Dunnett's t-test).

cyclin A in LNCaP cells, but the induction of FGF-8 mRNA, which is induced by testosterone in SC-3, was relatively low. Bicalutamide inhibited the cyclin A mRNA expression at $30 \mu \mathrm{M}$, but not for FGF-8. Interestingly, bicalutamide also inhibited the cyclin A mRNA expression in PC-3, but not in DU145 cells, at $30 \mu \mathrm{M}$. DHT had no effect on the inhibition by bicalutamide in PC-3 cells.

To investigate the time course of cyclin A mRNA induction, RT-PCR analysis was conducted with total RNA samples from the SC-3 cells at various time points from 4 to $24 \mathrm{~h}$ after the start of testosterone stimulation. In this experiment, DCC-FBS and testosterone were deprived for $48 \mathrm{~h}$ prior to testosterone stimulation to minimize possible effects of DCC-FBS and carry over effects of testosterone. As shown in Fig. 3D, serum deprivation for $48 \mathrm{~h}$ causes almost complete reduction in cyclin A and FGF-8 mRNA levels (-48h vs 0), indicating that effects of DCC-FBS and carry over effects of testosterone were negligible. Cyclin A mRNA induction was only seen after 24-h stimulation with testosterone. On the other hand, FGF- 8 mRNA induction was observed at $8 \mathrm{~h}$ and afterwards. Bicalutamide almost completely inhibited expression of these mRNAs by testosterone.

Western blot analysis of androgen-induced changes in cyclin A. As cyclin A mRNA level was upregulated by testosterone,
Western blot analysis was performed using anti-cyclin A monoclonal antibody to investigate whether or not cyclin A protein levels are affected by androgen and bicalutamide. It has been reported that approximately half of the growth promoting activity in the total extract of SC-3 cells was found to be extracellular matrix associated when stimulated with testosterone (21). Cyclin A protein expression was induced by $1 \mathrm{nM}$ of testosterone in SC-3 cells as observed in mRNA level. Bicalutamide $(1 \mu \mathrm{M})$ alone did not induce cyclin A protein expression, and completely inhibited the cyclin A protein expression induced by testosterone. Changes in FGF-8 protein levels in the cell lysates were not detected by testosterone or bicalutamide alone, but a slight increase was observed in the combination (Fig. 4A).

To confirm the effects in SC-3 cells, Western blot analysis was also conducted with the cell lysate from human prostate cancer cells (Fig. 4B). Cyclin A protein expression was downregulated by the replacement of the maintenance medium with serum-free medium in LNCaP cells, but upregulated in DU145 cells. In PC-3 cells, the replacement with serum-free medium did not affect cyclin A protein expression. In serumfree medium, DHT upregulated the cyclin A protein expression in LNCaP cells compared to the vehicle control, but had no effect in DU145 and PC-3 cells. Bicalutamide inhibited DHT-induced cyclin A protein expression in LNCaP cells, 
(A)

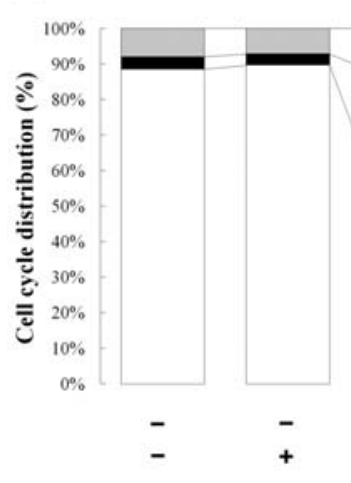

(B)

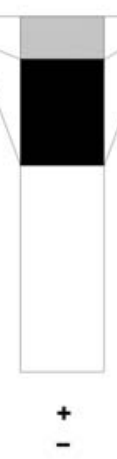

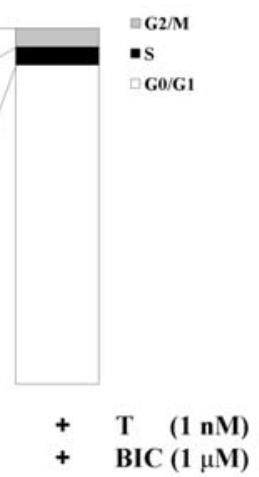

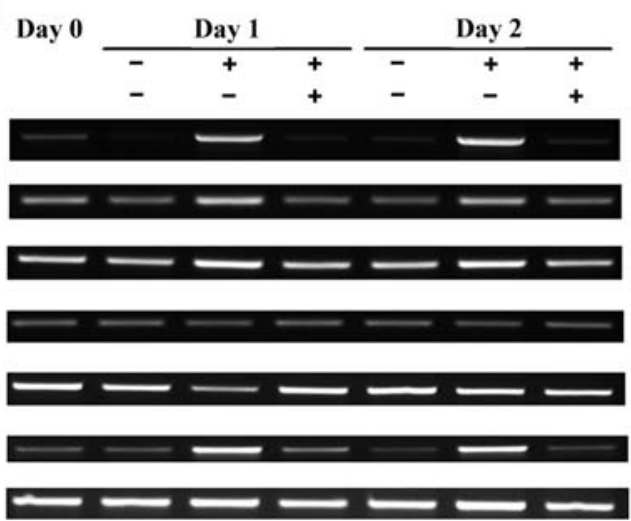

T (1 nM)

BIC $(1 \mu \mathrm{M})$

Cyclin A

Cyclin $D_{1}$

Cyclin E

p21 ${ }^{\text {Waft }}$

p2 $7^{\text {Kip1 }}$

FGF-8

GAPDH
(C)

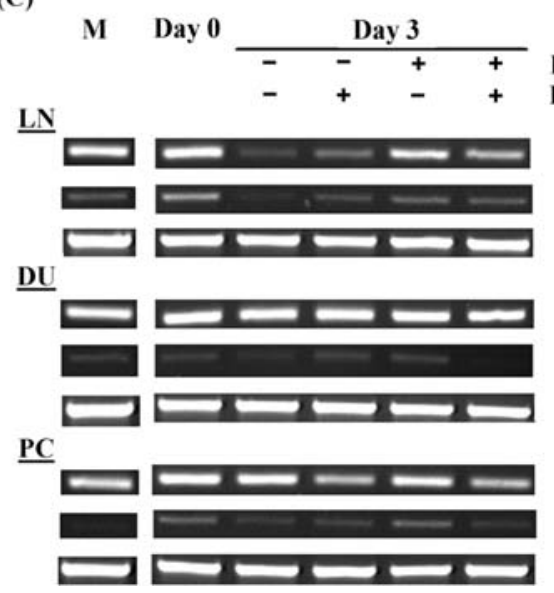

(D)

DHT $(10 \mathrm{nM})$
BIC $(30 \mu \mathrm{M})$
Cyclin A
FGF-8
GAPDH
Cyclin A
FGF-8
GAPDH
Cyclin A
FGF-8
GAPDH
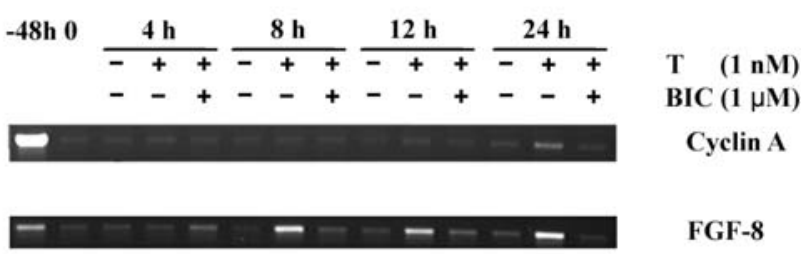

FGF-8

GAPDH

Figure 3. (A). Effect of testosterone and bicalutamide on cell cycle distribution. SC-3 cells were seeded into 100 -mm dishes (2x10 6 cells/dish) and medium was changed to HMB0.1 with or without testosterone $(1 \mathrm{nM})$ and bicalutamide $(1 \mu \mathrm{M})$ the following day (day 0$)$, and harvested on day 2 . Cells were fixed for $>4 \mathrm{~h}$ at $4^{\circ} \mathrm{C}$ with $70 \%$ ethanol and incubated with RNase A (final $100 \mu \mathrm{g} / \mathrm{ml}$ ) for 30 min at $37^{\circ} \mathrm{C}$ and the DNA intercalating dye, propidium iodide (final $50 \mu \mathrm{g} / \mathrm{ml}$ ) for $30 \mathrm{~min}$ at room temperature just before analysis by flow cytometry. T, testosterone; BIC, bicalutamide. Effects of androgen and bicalutamide on mRNA expression of cell cycle regulators and FGF-8 in SC-3 (B) and human PC (C) cells. (B) SC-3 cells were seeded into 100-mm dishes (2x10 cells/dish) and medium was changed to HMB0.1 with or without testosterone $(1 \mathrm{nM})$ and bicalutamide $(1 \mu \mathrm{M})$ the following day (day 0$)$, and harvested on days 1 or 2 . Total RNA isolation and RT-PCR was done as described in Materials and methods. (C) Cells were seeded into 60-mm dishes (5x105 cells/dish) and medium was changed to HMB0.1 with or without dihydrotestosterone (10 nM) and bicalutamide ( $30 \mu \mathrm{M})$ the following day (day 0$)$, and harvested on day 3 . Total RNA isolation and RT-PCR was done as described in Materials and methods. T, testosterone; DHT, dihydrotestosterone; BIC, bicalutamide; LN, LNCaP; DU, DU145; PC, PC-3. (D) Time course of testosterone induced mRNA expression of cyclin A and FGF-8. SC-3 cells were seeded into 100 -mm dishes (2x10 6 cells/dish) containing T-free MEM with $2 \%$ DCC-treated FBS. The following day ( $-48 \mathrm{~h})$, the medium was replaced with HMB0.1 medium without T. After two days of testosterone deprivation, medium was changed again to HMB0.1 medium with or without T ( $1 \mathrm{nM})$ and bicalutamide ( $1 \mu \mathrm{M})$ (time 0$)$. Cells were harvested at indicated hours of incubation. Total RNA isolation and RT-PCR was done as described in Materials and methods. T, testosterone; BIC, bicalutamide.

and also inhibited cyclin A protein expression regardless of the presence or absence of DHT both in DU145 and PC-3 cells. FGF-8 protein levels were variable but no significant effects of DHT and/or bicalutamide were observed in human prostate cancer cells. Bicalutamide had no effect on the FGF-8 protein expression in the cell lines tested.

Effects of anti-FGF-8 antibody and U0126 on the androgeninduced DNA synthesis and cyclin A mRNA expression. Since FGF-8 has shown to be critical for androgen-induced growth of SC-3 cells (22), anti-FGF8 monoclonal antibody and a MEK1/2 inhibitor, known to inhibit FGFR signalling, U0126 were used to investigate whether or not FGF- 8 has an intermediate role in the growth and the induction of cyclin $\mathrm{A}$ mRNA expression by androgen. As shown in Fig. 5A, antiFGF-8 antibody partially inhibited testosterone-induced (1 nM) DNA synthesis. U0126 showed concentration-dependent inhibition on androgen-induced growth in SC-3 and LNCaP cells (Fig. 5B). Furthermore, anti-FGF8 antibody inhibited cyclin A mRNA expression induced by testosterone (1 $\mathrm{nM})$ in SC-3 cells (Fig. 5C), suggesting that FGF-8 may be involved in cyclin A expression by androgen.

Effect of bicalutamide and U0126 on the FGF-8-induced DNA synthesis and cyclin A expression. The effect of bicalutamide on FGFR signalling was investigated indirectly by ${ }^{3} \mathrm{H}$-thymidine incorporation induced by recombinant FGF-8 (rFGF-8). rFGF-8 induced DNA synthesis both in LNCaP cells (Fig. 6A) and SC-3 cells (Fig. 6D). Bicalutamide partially inhibited the FGF-8-induced DNA synthesis in LNCaP cells (Fig. 6B), but not in SC-3 cells (Fig. 6C). U0126 showed concentration-dependent inhibition on $\mathrm{rFGF}-8$-induced DNA synthesis in SC-3 cells with $\mathrm{IC}_{50}$ value of $1.18(0.86-1.60) \mu \mathrm{M}$ (95\% confidence limits) (Fig. 6C). When DNA synthesis was co-stimulated with testosterone and $\mathrm{rFGF}-8$ in SC-3 cells, bicalutamide inhibited DNA synthesis only partially, almost 
(A)

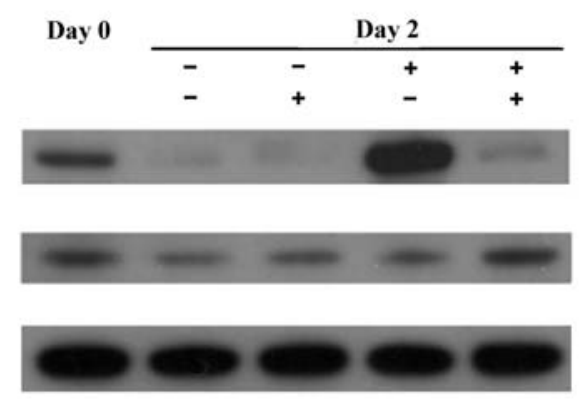

(B)

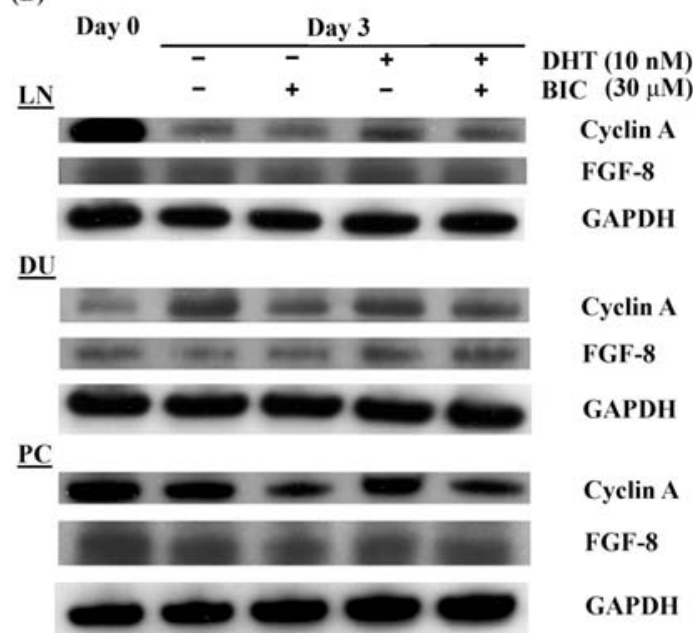

Figure 4. Androgen-induced cyclin A protein expression and inhibitory effect of bicalutamide. (A) SC-3 cells were seeded into 60-mm dishes (5x10 cells/ dish) and medium was changed to HMB0.1 with or without testosterone $(1 \mathrm{nM})$ and bicalutamide $(1 \mu \mathrm{M})$ the following day (day 0$)$, and harvested on day 2 . Cell lysate preparation and Western blotting analysis was done as described in Materials and methods. (B) Human prostate cancer cells were seeded into 60$\mathrm{mm}$ dishes $\left(5 \times 10^{5}\right.$ cells/dish) and medium was changed to HMB0.1 with or without dhydrotestosterone $(10 \mathrm{nM})$ and bicalutamide $(30 \mu \mathrm{M})$ the following day (day 0), and harvested on day 3. Cell lysate preparation and Western blotting analysis was performed as described in Materials and methods. T, testosterone; DHT, dihydrotestosterone; BIC, bicalutamide; LN, LNCaP; DU, DU145; PC, PC-3.

(A)

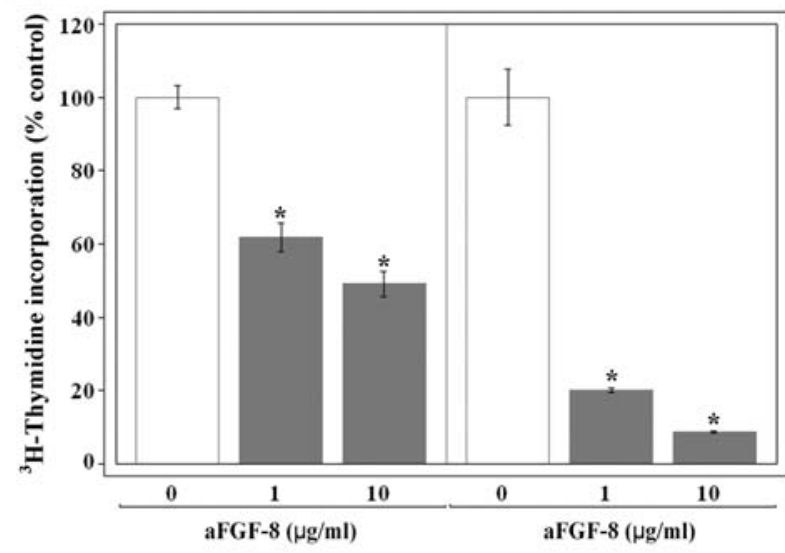

(C)

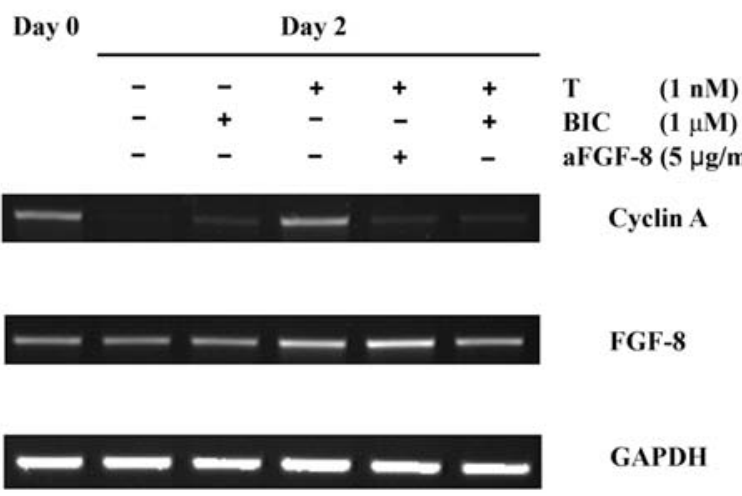

(B)

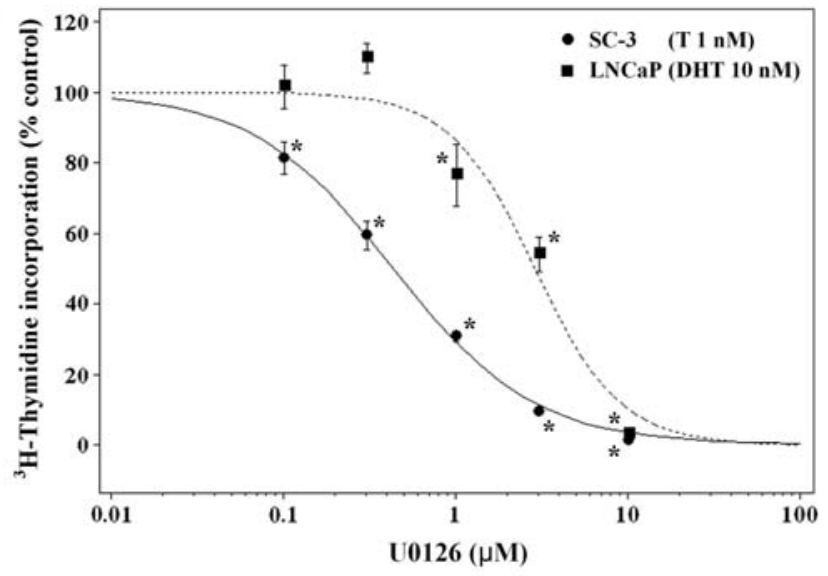

Figure 5. (A) Effect of anti-FGF8 monoclonal antibody on the testosterone-induced growth. Cells were seeded into a 96-well plate and pulsed with ${ }^{3} \mathrm{H}$-thymidine as described in Fig. 1, except for medium (HMB0.1) with testosterone $(1 \mathrm{nM})$ or rFGF-8 (40 ng/ml) and anti-FGF8 antibody at indicated concentrations. ${ }^{*} \mathrm{p}<0.05$ (comparison with vehicle control, Dunnett's t-test). (B) Concentration-dependent growth inhibitory effects of U0126 on androgen-induced growth $\left(\mathrm{n}=4\right.$, mean \pm SEM). Cells were seeded into a 96-well plate and pulsed with ${ }^{3} \mathrm{H}$-thymidine as described in Fig. 1, except for medium (HMB0.1) with testosterone (1 nM) for SC-3 cells or DHT (10 nM) for LNCaP cells, respectively, and various concentrations of U0126 (0.1-10 $\mu \mathrm{M})$. (C) Effect of anti-FGF8 monoclonal antibody on the testosterone-induced mRNA expression of cyclin A. SC-3 cells were seeded into 60-mm dishes (5x10 $\mathrm{cells} / \mathrm{dish})$ and medium was changed to HMB0.1 with or without testosterone $(1 \mathrm{nM})$, bicalutamide $(1 \mu \mathrm{M})$ and anti-FGF8 antibody $(5 \mu \mathrm{g} / \mathrm{ml})$ the following day (day 0), and harvested on day 2. Total RNA isolation and RT-PCR was done as described in Materials and methods. T, testosterone; BIC, bicalutamide; aFGF-8, antiFGF-8 monoclonal antibody. 
(A)

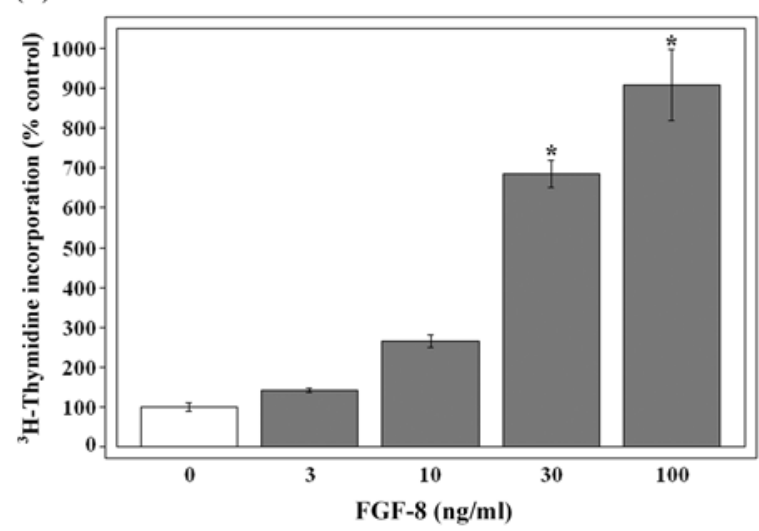

(C)

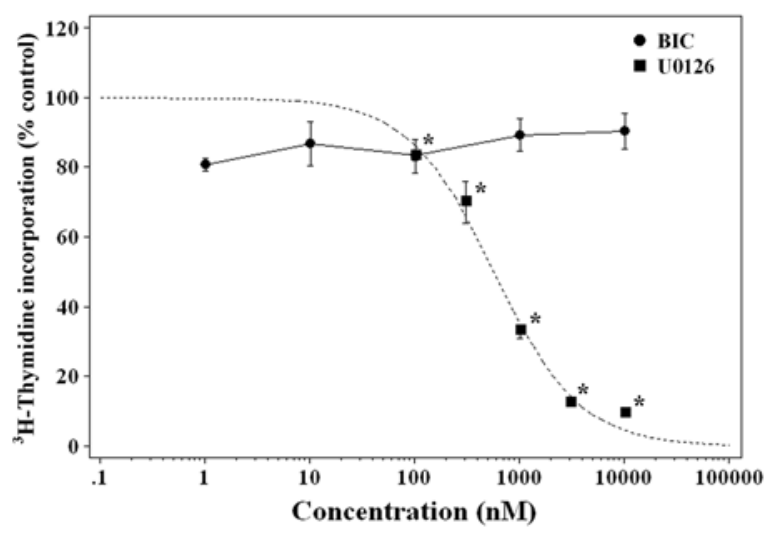

(B)

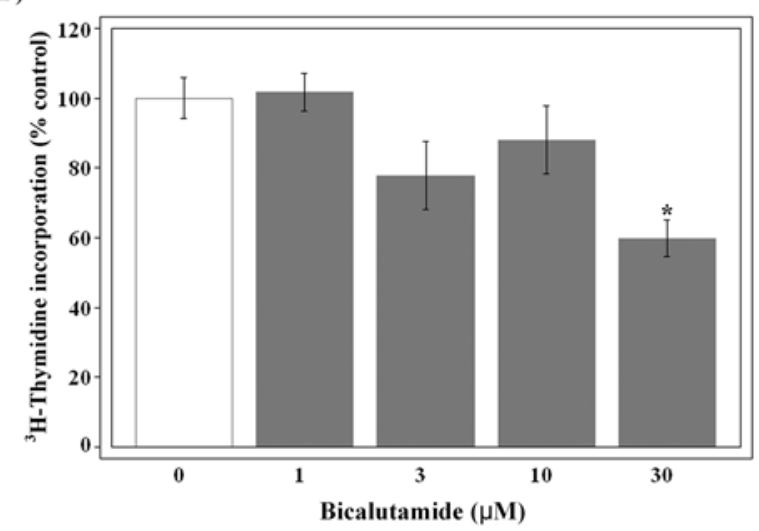

(D)

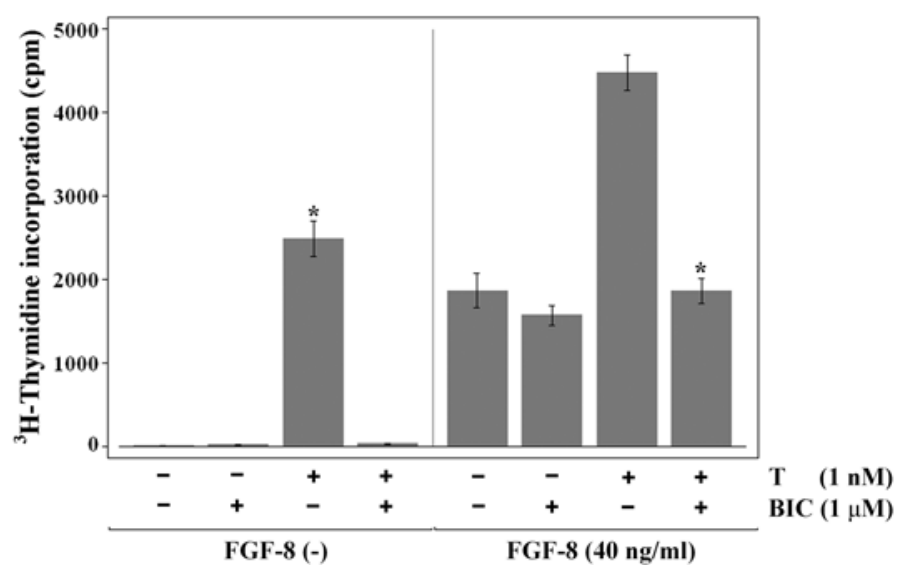

Figure 6. Growth inhibitory effects of bicalutamide and U0126 on androgen and/or rFGF-8 induced growth (mean \pm SEM, $n=4$ ). (A) LNCaP cells were seeded into a 96 -well plate and pulsed with ${ }^{3} \mathrm{H}$-thymidine as described in Fig. 1, except for medium (HMB0.1) with various concentrations of $\mathrm{rFGF}-8$ (0-100 ng/ml). ${ }^{*} \mathrm{p}<0.05$ (comparison with vehicle control, Dunnett's t-test). (B) LNCaP cells were seeded into a 96-well plate and pulsed with ${ }^{3} \mathrm{H}$-thymidine as described in Fig. 1, except for medium (HMB0.1) with rFGF-8 $(30 \mathrm{ng} / \mathrm{ml})$ and various concentrations of bicalutamide $(0-30 \mu \mathrm{M})$. "p $<0.05$ (comparison with vehicle control, Dunnett's t-test). (C) SC-3 cells were seeded into a 96-well plate and pulsed with ${ }^{3} \mathrm{H}$-thymidine as described in Fig. 1, except for medium (HMB0.1) with rFGF-8 $(40 \mathrm{ng} / \mathrm{ml})$ and various concentrations of bicalutamide $(1 \mathrm{nM}-10 \mu \mathrm{M})$ or U0126 $(0.1-10 \mu \mathrm{M}) .{ }^{*} \mathrm{p}<0.05$ (comparison with vehicle control, Dunnett's t-test). (D) SC-3 cells were seeded into a 96-well plate and pulsed with ${ }^{3} \mathrm{H}$-thymidine as described in Fig. 1, except for medium (HMB0.1) with or without testosterone $(1 \mathrm{nM})$, rFGF-8 $(40 \mathrm{ng} / \mathrm{ml})$ and bicalutamide $(1 \mu \mathrm{M})$. T, testosterone; BIC, bicalutamide. "p $<0.05$ (comparison with vehicle control, Dunnett's t-test), " $\mathrm{p}<0.05$ (comparison with rFGF-8 alone, Dunnett's t-test).

Day 3

\begin{tabular}{|c|c|c|c|c|c|c|}
\hline - & - & + & + & - & - & DHT $\quad(10 \mathrm{nM})$ \\
\hline - & + & - & + & - & + & BIC $\quad(30 \mu \mathrm{M})$ \\
\hline - & - & - & - & + & + & FGF-8 $(30 \mathrm{ng} / \mathrm{ml})$ \\
\hline
\end{tabular}

\section{$\longrightarrow$}

Figure 7. FGF-8-induced cyclin A mRNA expression and inhibitory effect of bicalutamide in LNCaP cells. Cells were seeded into $60-\mathrm{mm}$ dishes $\left(5 \times 10^{5}\right.$ cells/dish) and medium was changed to HMB0.1 with or without dihydrotestosterone $(10 \mathrm{nM})$, rFGF-8 $(30 \mathrm{ng} / \mathrm{ml})$ and bicalutamide $(30 \mu \mathrm{M})$ on day 3. Total RNA isolation and RT-PCR was done as described in Materials and methods. DHT, dihydrotestosterone; BIC, bicalutamide.

identically to the effects derived from testosterone (Fig. 6D). rFGF-8 induced cyclin A mRNA expression in LNCaP cells, but the effect of bicalutamide on the cyclin A expression induced by rFGF- 8 was limited compared to the one induced by DHT (Fig. 7).

\section{Discussion}

Cyclin A is a key cell cycle regulator in the S phase of the cell cycle through its interaction with CDK1 and 2, key kinases in both $\mathrm{S}$ phase and mitosis (23). Many investigations on the link between cancer and aberration in cell cycle regulation have been done, suggesting the importance of cyclin A overexpression in hormone responsive cancers, such as breast cancer and prostate cancer (23-25). The results of the present study were consistent with these clinical findings. In addition, the results also suggest that cyclin A may be one of the key molecules in androgen-induced tumor cell growth since the growth of SC-3 cells are highly-dependent on androgen $(7,8)$. The induction by androgen was also observed in human androgen-sensitive LNCaP cells at serum-free condition, but not in androgen-insensitive human prostate cancer cell lines, suggesting that the induction was purely an androgendependent effect.

Menjo et al reported that a CKI, p27kip1 plays a critical role in cell cycle arrest after androgen depletion in SC-3 cells, and that no apparent changes were seen in cyclin A protein levels (26). The difference between the results of Menjo et al and 
ours may be due to the difference in the methodology used. Menjo et al focused on the effects of androgen depletion from maintenance medium containing $100 \mathrm{nM}$ of testosterone. If the SC-3 cells were maintained with high concentration of testosterone, they might be less sensitive to testosterone; in fact significant growth stimulation was seen only after 3 days of culture in their study whereas significant stimulation of DNA synthesis was seen after 2-day culture with physiological concentration, i.e., 1-10 nM testosterone in ours. Therefore, the effects of testosterone on cyclin A expression could be masked in their study.

As previously mentioned, FGF-8 is critical for androgendependent growth of SC-3 cells. In this experiment, we have shown that FGF-8 gene expression was reduced by deprivation of DCC-FBS and testosterone and that it was induced by only $8 \mathrm{~h}$ of testosterone stimulation. Thus, FGF- 8 gene expression was highly dependent on testosterone and seen at a very early stage of the induction of the growth. However, a stable transfectant of SC-3 cells expressing FGF-8 gene did not grow in serum-free medium unless stimulated with androgen (27), suggesting that other molecules may also be essential for androgen-dependent growth. Although the detailed mechanism of cyclin A induction remains to be elucidated, inhibitory effects of a pure anti-androgen, bicalutamide, on cyclin A and FGF-8 gene expression, and the fact that induction of cyclin A mRNA was preceded by that of FGF-8 suggest that testosterone induces cyclin A expression via FGF-8 in SC-3 cells. This hypothesis is supported by the fact that a MEK1/2 inhibitor U0126 completely inhibited DNA synthesis induced by androgen (Fig. 5) and that rFGF-8 induced cyclin mRNA expression (Fig. 7). Induction of cyclin A has been reported in other FGF-FGFR systems $(28,29)$, but not for FGF-8. Anti-FGF-8 monoclonal antibody inhibited the cyclin A mRNA expression but did not completely inhibit the testosterone $(1 \mathrm{nM})$-induced DNA synthesis in SC-3 cells at the concentration where cyclin A mRNA expression was almost completely inhibited (Fig. 5) (30). Although FGF-8 is the most important and critical growth factor of androgen-induced growth of SC-3 cells (21), it could not substitute androgen by itself to maintain the cell line, suggesting that another factor(s) is also involved in testosterone-induced effects in SC-3 cells (27).

Interestingly, bicalutamide partially inhibited both DNA synthesis and cyclin A expression in androgen-insensitive human prostate cancer cell lines. These findings suggest bicalutamide may have another growth inhibitory mechanism of action on the human prostate cancer cells because the effects were seen at $30 \mu \mathrm{M}$, which is comparable to the plasma concentration in man after chronic oral administration of bicalutamide (31), but it needs to be investigated further, e.g investigation using the AR-positive but androgeninsensitive cell lines.

It is well known that extracellular matrix proteins are essential for the interaction between FGF and FGF receptors (32). We investigated the FGF-8 protein expression in human prostate cancer cells and SC-3 cells by Western blotting. In human prostate cancer cell lines, there was no obvious difference in FGF-8 protein level between the cell lysates derived from androgen-treated and controls both in androgen-sensitive and -insensitive cell lines by Western blotting. However, FGF-8 protein slightly increased in SC-3 cells treated with testosterone and bicalutamide compared to the vehicle control. The mechanism of this increase is yet to be investigated. Given that Western blotting has been performed with whole cell lysates, one hypothesis would be that bicalutamide might block FGF-8 protein secretion and/or folding of the protein by extracellular matrix protein such as heparin sulphate.

Bicalutamide showed inhibitory effects on testosteroneinduced FGF-8 mRNA expression, but had not effect on FGF-8-induced DNA synthesis in SC-3 cells. In the human prostate cancer cell line LNCaP, bicalutamide showed concentration-dependent inhibition on the DHT-induced DNA synthesis, but had no or limited effect on androgenindependent or FGF-8-induced DNA synthesis, and FGF-8induced cyclin A expression. Although crosstalk between androgen receptor and growth factor receptor signalling pathways has already been reported widely, there may be no or little interaction with FGFR. Androgen may affect not only the transcription of the FGF-8 gene but also the FGF-8 protein secretion and/or folding of the protein by extracellular matrix protein such as heparin sulphate. Furthermore, the MEK1/2 inhibitor U0126, known to inhibit FGFR signalling, did inhibit androgen-induced DNA synthesis both in SC-3 and LNCaP cells in our experiment and it has been reported that stable transfection of the dominant negative FGFRs inhibited colony formation of LNCaP cells (33). These findings suggest that androgen-sensitive cells are highly dependent on FGFR signal transduction. Taken together, it is considered that by inducing both the mRNA expression of FGF- 8 gene and FGF- 8 protein secretion, androgen can trigger DNA synthesis and cyclin A expression in SC-3 cells, which may also contribute to the growthpromoting effects in human prostate cancer cells. Complete inhibition of bicalutamide on the androgen-induced DNA synthesis may also be achieved via its effects on both pathways.

Overall, bicalutamide inhibited androgen-induced cyclin A mRNA and protein expression in androgen-sensitive cells by inhibiting the FGF-8 mRNA expression and possibly by FGF-8 protein secretion. Effects of bicalutamide on FGF-8 signalling is limited, so an inhibitor of FGFR signalling may provide additional effects to anti-androgens with regards to androgen-induced cell growth. Bicalutamide also inhibited cyclin A mRNA and protein expression in androgenindependent cells, suggesting that other mechanisms may also be involved in the inhibitory effects of bicalutamide. It is also suggested that cyclin A could be a sensitive marker for androgen-induced cancer growth and for the growth inhibitory effect of anti-androgen. The significance of our findings should be confirmed in further experiments, e.g. the effects of androgens and anti-androgens on the cell-associated FGF-8 levels in relation to the cell cycle, or experiment with tumor tissues derived from patients with human prostate cancer.

\section{Acknowledgements}

We thank Dr Norimitsu Inoue for his helpful suggestions and Ms. Yumiko Tanigaki for her technical assistance. 


\section{References}

1. Festuccia C, Gravina GL, Angelucci A, Millimaggi D, Muzi P, Vicentini C, et al: Additive antitumor effects of the epidermal growth factor receptor tyrosine kinase inhibitor, gefitinib (Iressa), and the nonsteroidal antiandrogen, bicalutamide (Casodex), in prostate cancer cells in vitro. Int J Cancer 115: 630-640, 2005.

2. Culig Z: Role of the androgen receptor axis in prostate cancer. Urology 62 (Suppl. 5A): S21-S26, 2003.

3. Lee $\mathrm{HJ}$ and Chang C: Recent advances in androgen receptor action. Cell Mol Life Sci 60: 1613-1622, 2003.

4. Culig Z, Klocker H, Bartsch G and Hobisch A: Androgen receptors in prostate cancer. Endocr Relat Cancer 9: 155-170, 2002.

5. Kooijman R, Himpe E, Potikanond S and Coppens A: Regulation of interleukin-8 expression in human prostate cancer cells by insulin-like growth factor-I and inflammatory cytokines. Growth Horm IGF Res 17: 383-391, 2007.

6. Minesita T and Yamaguchi K: An androgen-dependent tumor derived from a hormone-independent spontaneous tumor of a female mouse. Steroids 4: 815-830, 1964.

7. Nakamura N, Nishizawa Y, Noguchi S, Uchida N, Sato B and Matsumoto K: Action mechanisms of physiological doses of androgen or pharmacological doses of estrogen in growth stimulation of Shionogi carcinoma 115 in mice. J Steroid Biochem 27: 459-464, 1987

8. Yamanishi H, Tanaka A, Miyamoto K, Takeda M, Nishizawa Y, Koga M, et al: An essential role of androgen-induced growth factor in glucocorticoid-dependent autocrine loop in Shionogi carcinoma 115 cells. J Steroid Biochem Mol Biol 52: 49-53, 1995.

9. Gnanapragasam VJ, Robson CN, Neal DE and Leung HY: Regulation of FGF-8 expression by androgen receptor in human prostate cancer. Oncogene 21: 5069-5080, 2002.

10. Ruohola JK, Viitanen TP, Valve EM, Seppänen JA, Loponen NT, Keskitalo JJ, et al: Enhanced invasion and tumor growth of fibroblast growth factor 8b-overexpressing MCF-7 human breast cancer cells. Cancer Res 61: 4229-4237, 2001.

11. Diez C, Bertsch G and Simm A: Isolation of full-size mRNA from cells sorted by flow cytometry. J Biochem Biophys Methods 40: 69-80, 1999

12. Qian X, Kulig E, Jin L and Lloyd RV: Expression of D-type cyclins in normal and neoplastic rat pituitary. Endocrinology 139: 2058-2067, 1998.

13. Fang M-Z, Mar W-C and Cho M-H: Cell cycle was distributed in the MNNG-induced initiation stage during in vitro two-stage transformation of Balb/3T3 cells. Toxicology 163: 175-184, 2001.

14. Gartel AL, Ye X, Goufman E, Shianov P, Hay N, Najmabadi F, et al: Myc represses the $\mathrm{p} 21^{(\mathrm{WAF} 1 / \mathrm{CIP} 1)}$ promotor and interacts with Sp1/Sp3. Proc Natl Acad Sci USA 98: 4510-4515, 2001.

15. Grayson JM, Murali-Krishna K, Altman JD and Ahmed R: Gene expression in antigen-specific $\mathrm{CD}^{+} \mathrm{T}$ cells during viral infection. J Immunol 166: 795-799, 2001.

16. Patel AC, Anna CH, Foley JF, Stockton PS, Tyson FL, Barrett JC et al: Hypermethylation of the p16 $6^{\mathrm{INK} 4 \mathrm{a}}$ promotor in $\mathrm{B} 6 \mathrm{C} 3 \mathrm{~F} 1$ mouse primary lung adenocarcinomas and mouse lung cell lines. Carcinogenesis 21: 1691-1700, 2000.

17. Tanaka A, Miyamoto K, Matsuo H, Matsumoto $\mathrm{K}$ and Yoshida $\mathrm{H}$ : Human androgen-induced growth factor in prostate and breast cancer cells: its molecular cloning and growth properties. FEBS Lett 363: 226-230, 1995 .
18. Shi XB, Ma AH, Tepper CG, Xia L, Gregg JP, GandourEdwards R, et al: Molecular alterations associated with LNCaP cell progres-sion to androgen independence. Prostate 60: 257271,2004

19. Dobashi Y, Jiang SX, Shoji M, Morinaga S and Kameya T: Diversity in expression and prognostic significance of $\mathrm{G} 1 / \mathrm{S}$ cyclins in human primary lung carcinomas. J Pathol 199: 208-220, 2003.

20. Darbre PD and King RJB: Antiandrogen ICI 176334 does not prevent development of androgen insensitivity in S115 mouse mammary tumor cells. J Steroid Biochem 36: 385-389, 1990.

21. Sumitani S, Kasayama S and Sato B: A role for heparan sulfate in androgen-induced deoxiribonucleic acid synthesis of mouse mammary carcinoma (Shionogi carcinoma 115)-derived SC-3 cells. Endocrinology 132: 1199-1206, 1993.

22. Sato B: Can an autocrine loop explain sex-hormone-dependent tumor growth? Oncology 57 (Suppl. 2): S3-S6, 1999.

23. Yam CH, Fung TK and Poon RYC: Cyclin A in cell cycle control and cancer. Cell Mol Life Sci 59: 1317-1326, 2002.

24. Bukholm IRK, Bukholm G and Nesland JM: Over-expression of cyclin A is highly associated with early relapse and reduced survival in patients with primary breast carcinomas. Int $\mathrm{J}$ Cancer 93: 283-287, 2001.

25. Aaltomaa S, Eskelinen M and Lipponen P: Expression of cyclin $\mathrm{A}$ and $\mathrm{D}$ proteins in prostate cancer and their relation to clinopathological variables and patient survival. Prostate 38: 175-182, 1999.

26. Menjo M, Kaneko Y, Ogata E, Ikeda K and Nakanishi M: Critical role for $\mathrm{p} 27^{\mathrm{Kip} 1}$ in cell cycle arrest after androgen depletion in mouse mammary carcinoma cells (SC-3). Oncogene 17: 2619-2627, 1998

27. Miyashita Y, Koga M, Kouhara H, Tanaka A, Kishimoto T and Sato B: Facilitation of autonomous phenotype acquisition in androgen-dependent Shionogi carcinoma 115 cells by transfection of androgen-induced growth factor expression vector. Jpn J Cancer Res 85: 1117-1123, 1994.

28. Tomono M, Toyoshima K, Ito M, Amano H and Kiss Z: Inhibitors of calcineurin block expression of cyclins $\mathrm{A}$ and $\mathrm{E}$ induced by fibroblast growth factor in Swiss 3T3 fibroblasts. Arch Biochem Biophys 353: 374-378, 1998.

29. Schultz K, Fanburg BL and Beasley D: Hypoxia and hypoxiainducible factor-1alpha promote growth factor-induced proliferation of human vascular smooth muscle cells. Am J Physiol Heart Circ Physiol 290: H2528-H2534, 2006.

30. Goto GH, Katayama H, Tanigaki Y, Fushiki S, Nishizawa Y and Nishizawa Y: Methylcobalamin inhibits fibroblast growth factor-8 stimulated proliferation and induces apoptosis in Shionogi carcinoma cells. Int J Vitam Nutr Res 78: 21-26, 2008.

31. Tyrrell CJ, Denis L, Newling D, Soloway M, Channer K and Cockshott ID: Casodex 10-200 mg daily, used as monotherapy for the treatment of patients with advanced prostate cancer. An overview of the efficacy, tolerability and pharmacokinetics from three phase II dose-ranging studies. Eur Urol 33: 39-53, 1998

32. Kwabi-Addo B, Ozen M and Ittmann M: The role of fibroblast growth factors and their receptors in prostate cancer. Endocr Relat Cancer 11: 709-724, 2004.

33. Ozen M, Giri D, Ropiquet F, Mansukhani A and Ittmann M: Role of fibroblast growth factor receptor signaling in prostate cancer cell survival. J Natl Cancer Inst 93: 1783-1790, 2001. 